\title{
Implications of Socioeconomic Status on Academic Competence: A Perspective for Teachers
}

\author{
Luis F. Cedeño ${ }^{1}$, Rosario Martínez-Arias ${ }^{2}$ \& José A. Bueno ${ }^{1}$ \\ ${ }^{1}$ Facultad de Educación, Universidad Complutense de Madrid, Madrid, Spain \\ ${ }^{2}$ Facultad de Psicología, Universidad Complutense de Madrid, Madrid, Spain \\ Correspondence: Luis F. Cedeño, Facultad de Educación, Departamento de Psicología Evolutiva y de la Educación, \\ Despacho 4208, Universidad Complutense de Madrid, Edificio La Almudena, C/Rector Royo Villanova s/n, Ciudad \\ Universitaria 28040-Madrid, Spain. Tel: 34-91-172-9819. E-mail: luiscede@ucm.es
}

Received: September 16, 2015 Accepted: October 27, 2015 Online Published: March 29, 2016

doi:10.5539/ies.v9n4p257 URL: http://dx.doi.org/10.5539/ies.v9n4p257

\begin{abstract}
Studies suggest that socioeconomic status is a strong predictor of academic achievement. This theoretical paper proposes that despite the fact that low-socioeconomic status represents a risk factor that seems to undermine attentional skills and thus academic achievement, emerging evidence suggests the potential of new approaches, interventions and cognitive training programs to reverse the negative effects of poverty. The evidence presented in this paper may be of particular interest for teachers because it provides a larger scope to better understand the implications of socioeconomic status on learning and school achievement. This paper intends to make teachers aware that today more than ever they count on important knowledge and valuable resources like cognitive training intervention programs to help students. These intervention programs correct dysfunctional attention bringing hope to socially disadvantaged students who struggle in school.
\end{abstract}

Keywords: attention, underachievement, SES, competence, maltreatment, stress, HPA axis

\section{Introduction}

The present study highlights the graded relationship between socioeconomic status (SES) and academic achievement. Emerging evidence suggests that SES is a predictor of academic achievement. In fact, a body of research supports the notion that problematic attention is the hallmark of lower-income students and that this deficit is strongly associated to academic achievement (Caspi, Wright, Moffit, \& Silva, 1998; Farah \& Hackman, 2012; Neville et al., 2013; Sampson, Sharkey, \& Raudenbush, 2007; Stevens, Lauinger, \& Neville, 2009). Poor or lower-SES environments seem to generate significant stress on individuals compromising selective attention with implications for academic achievement.

We are afraid that such evidence may tempt some teachers and policy makers to believe that academic underachievement among socially disadvantaged students are an irreversible and inevitable outcome. With this in mind, this paper intends to provide a different perspective by indicating that certain characteristics like personal traits and the influence of a caring adult like a teacher, provides the pillars to reverse the harmful effects of poverty. Besides, the implementation of intervention and cognitive training programs are potentially beneficial, correcting cognitive features such as maladaptive information processing styles that impede school achievement (D’Angiulli, Herdman et al., 2008; D’Angiulli, Weinbergh et al., 2008; Lutz et al., 2009; Neville et al., 2013; Stevens \& Bavelier, 2012). Consequently, we believe that teachers are in a particularly optimal position to help students with attentional problems. Teachers can refer them to cognitive training programs that enhance selective attention.

It is worth noting that although disorders like depression, schizophrenia, attention deficit disorder (ADD) and attention deficit hyperactivity disorder (ADHD) have been linked to attention, they should not be confused with attention dysfunction which is the central theme of this paper (Lutz et al., 2009).

Our research question is the following: Can low-income students with proper support improve academic performance?

Despite the fact that this paper neither provides empirical data on the effectiveness of one particular cognitive program against another, nor the evidence discussed here is comprehensive, it does provide important insights on 
cognitive training programs that enhance attention control.

This manuscript includes the following sections:

- Why not to blame the poor

- Poverty related stress: maltreatment and neglect

- Attention among low-income students

- Protective factors

- Interventions and brain plasticity

- Answer to research question

\section{Why Not to Blame the Poor}

The world recession increased unemployment and millions became poor and struggle to meet their basic needs. Poverty is a risk factor that brings about segregation, violence, poor health, and school underachievement. Poor or low-income families are, in the first place, more likely to have partial or no health insurance coverage and therefore, tend to suffer more diseases and reduced life expectancy (Alley, Seeman, Kim, $\mathrm{Hu}$, \& Crimmins, 2006). According to Alley et al. (2006), low-income individuals develop earlier conditions like heart disease, diabetes, cancer and psychological issues. Lack of opportunities, isolation, and community and domestic violence seem endemic in lower-SES environments, leading to dysfunctional problems (Doll \& Lyon, 1998). Under these circumstances the prospects of achieving academic success are significantly reduced (Caspi, Wright, Moffit, \& Silva, 1998; Turner, Popkin, \& Rawlings, 2008).

Life for low-income people is particularly difficult because they experience a plethora of needs and life issues that better-off individuals do not face and do not understand. In that sense, Mani, Mullainathan, Shafir, and Zhao (2013) seek to offer a different view related to unfair allegations about the poor as careless individuals, unproductive at work, that neglect health care and spend and ought too much. For Mani et al. (2013) it is clear that an individual with few resources and insufficient external support that attempts to comply with the demands of family and the demands of financial obligations, face a formidable task. Economic scarcity represents an important source of stress that limits choices and reduces the capacity to make effective decisions (Shah, Mullainathan, \& Shafir, 2012).

Mani et al. (2013) argue that better-off individuals are able to fulfill family expenses easily, but individuals in contexts of economic scarcity have accumulated debts, important decisions to make and more negative consequences to suffer if they err. The direct effect of this constant pressure is the attention completely focused on the demands of economic issues. The daily struggle to make ends meet activates a survival mechanism that makes them neglect or prioritize on other needs, disregarding, for example, proper supervision of their children (Mani et al., 2013).

Mani et al. (2013) believe that the pressure to cover basic needs explains why low-income individuals take decisions differently. For example, when they pay to have their car repaired, then, they would not have money left to pay for home utilities, or if they attend an appointment at their children's school, they would not have time to attend another important appointment elsewhere. All these strains produce a scarcity mindset that taxes cognitive functions (Mani et al., 2013; Shah et al., 2012).

Poor or low-SES individuals experience greater occurrence of conflicts because disorganization, instability and unpredictability co-occur with other negative events (Brooks-Gunn \& Duncan, 1997; Drake \& Pandey, 1996; Dube et al., 2003; Evans \& Kim, 2013). Residential instability, crowding, noise, toxins, cold, illness, and violence are common constraints of people living in poverty.

\section{Poverty Related Stress: Maltreatment and Neglect}

Poverty clearly puts children at greater risk of maltreatment. As poor environments tend to be chaotic, higher levels of stress are generated in the family and harsher parental discipline arises increasing the risk of maltreatment and neglect (Drake \& Pandey, 1996; Schibilli \& D’Angiulli, 2011; Steinberg, Catalano, \& Dooley, 1981). Often, acute stress is generated at prenatal stages due to the overlapping of several risk factors, for example, when a pregnant woman suffer gender violence, get involved in drugs, and do not follow medical care during pregnancy (Chaffin, Kelleher, \& Hollenberg, 1996). Furthermore, after a child's birth stress increases on the family and the whole situation worsens becoming unbearable and potentially detrimental for the developing child (Cicchetti, Rogosh, Gunnar, \& Toth, 2010; Cicchetti \& Toth, 2005; Danese \& McEwen, 2012; Hoff, 2003; Rogosh, Dackis, \& Cicchetti, 2011). 
Not all children respond the same before traumatic experiences. Several characteristics related to age, gender, frequency of exposure, and degree of resilience, as well as the physical proximity to the violent events determine the children's developmental outcomes (Wegman \& O'Banion, 2013). Although some children demonstrate resilience and bounce back from adversity, many others suffer permanent sequelae including chronic trauma that impacts daily functioning (Blaustein \& Kininburgh, 2010).

Emerging research suggests that chronic stress is strongly associated with overreactivity of the amygdala and inhibition of hippocampal functioning that compromise higher-order cognitive control (Cicchetti \& Toth, 2005; Danese \& McEwen, 2012). Social inequality generates significant stress that hinders mental adjustment (Alley et al., 2006; D'Angiulli, Lipina, \& Olesinska, 2012; Evans \& Kim, 2013), predisposes to learned helplessness (Abramson et al., 1978), hopelessness (Bolland, 2003), and lack of competence (D'Angiulli et al., 2012; Masten, Desjardins, McCormick, Kuo, \& Long, 2010).

\subsection{Stress and Competence}

SES plays a critical role in the development of competence which is central for school attainment (Sampson et al., 2007). At school, students develop competence that will determine the way they make decisions and solve problems (Masten et al., 2010). But poverty generates severe stress that disrupts important domains like competence (Caspi, Wright, Moffit, \& Silva, 1998; Duncan, 2012; Masten et al., 2010; Pérez and Widom, 1994; Zielinsky, 2009). Farah and Hackman (2012) are of the opinion that lower-SES environments also lead to poor cognitive stimulation because low-income children tend to have fewer books and toys, less reading at home, and fewer visits to places that enhance culture like museums. In addition, poor parents have lower expectations and less concern about their children's vocabulary acquisition (Farah \& Hackman, 2012). Severe stress and deficient cognitive stimulation have long-lasting effects on the individual's competence and this becomes more apparent at school or at work.

\subsection{The HPA Axis}

Studies show the significant impact of stress at a neurophysiological level. Stress increases the secretion of corticotrophin releasing hormones by the hypothalamus, stimulating the pituitary gland which in turn produces adrenocorticotropic hormones, activating the adrenal glands and increasing the levels of adrenaline and cortisol (the stress hormone; Delahanty, Nugent, Christopher, \& Walsh, 2005). This adaptive mechanism known as the hypothalamus-pituitary-adrenal (HPA) axis (see Figure 1), when chronic, represents a marker of wear and tear or allostatic load associated with changes in the metabolic process, reduced dendritic branching, and deficits in attention and learning (Cicchetti \& Rogosh, 2007; Danese \& McEwen, 2012; Hackman \& Farah, 2009; Hackman, Farah, \& Meaney, 2010). 


\section{HPA Axis}

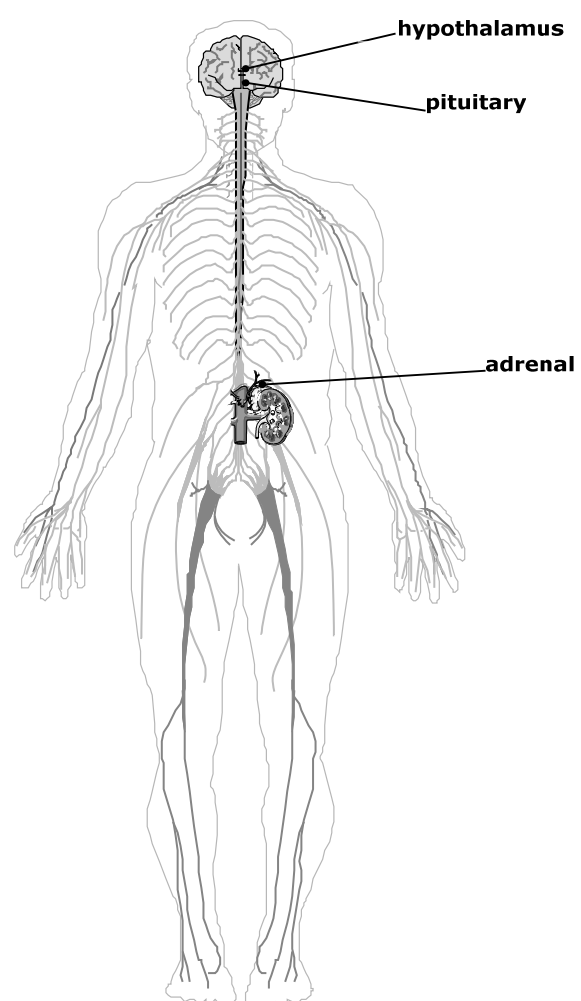

Figure 1. The hypothalamus-pitutitary-adrenal (HPA) axis

Chronic stress can also lead to epigenetic modifications, that is, changes in the gene expression, increasing even more the risk of health issues across the lifespan (Evans, Chen, Miller, \& Seeman, 2012). Chronic stress disrupts other important children domains such as attachment and self-regulation (Blaustein \& Kinniburgh, 2010). The interference of self-regulatory mechanisms impedes young brains to adapt and learn effective ways to cope with stress.

\section{Attention among Low-Income Students}

Chronic stress is detrimental for learning because it compromises executive functions such as problem-solving, decision-making, planning, working memory (i.e., a cognitive system closely linked to complex cognitive tasks involved in language comprehension, learning and reasoning), and attention (Blaustein \& Kinniburgh, 2010; Teicher, Anderson, \& Polcari, 2012; Tottenham, \& Sheridan, 2009).

As noted, problems of attention are more common among lower-income students (see Figure 2). They tend to experience more serious adversities at an early age that may lead to learned sustained vigilance, leading to focus attention on the identification of threats and missing relevant information as it seems to happen in intellectually demanding contexts like classrooms (Neville et al., 2013; Schibli \& D'Angiulli, 2011; Shackman, Shackman, \& Pollack, 2007). 


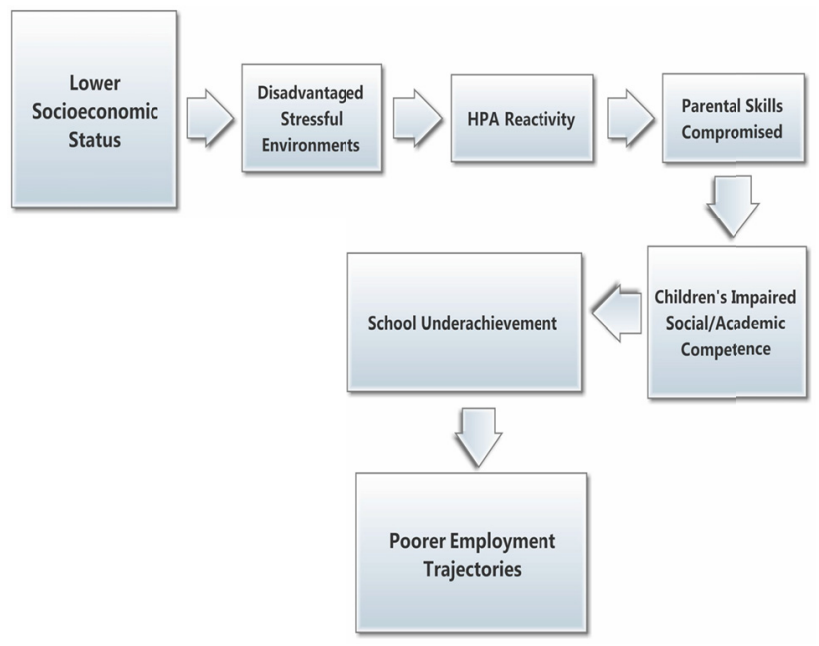

Figure 2. Effects of stress by poverty

Neuroscience studies seem to confirm a higher prevalence of attentional deficits among lower-SES students that might explain the academic achievement gap. For example, D'Angiulli, Herdman et al. (2008) studied 28 children and found that lower-SES children displayed less selective attention than higher-SES children. In another study that involved 28 children and that included salivary cortisol tests, D'Angiulli, Weinberg et al. (2008) determined that lower-SES children showed more deficits in attention and more disparities in cortisol levels than higher-SES children. Similarly, Stevens, Laugier, and Neville (2009) studied a cohort of 32 children and findings also indicated less selective attention among socially disadvantaged children. A more recent study with 28 children, D'Angiulli, Van Roon et al. (2012) confirmed differences in attention and cortisol levels between lower-income and higher-income children.

In similar fashion, Shackman, Shackman, and Polack (2007) analyzed the effect of maltreatment on attentional skills in 36 children regardless of socioeconomic backgrounds. Findings revealed that the group of maltreated children displayed less selective attention than the non-maltreated group, supporting the notion that severe stress, regardless of SES has indeed significant impact on children's brain functions.

It is worth pointing out that some authors do not consider negative the attentional differences displayed by lower-income students (see for example, D'Angiulli, Herdman et al., 2008; D'Angiulli, Van Roon et al., 2012). These authors speculate that differences in attention are the result of an alternative way of processing information in which lower-income children implement a combination of adjustment ability and compensatory resources developed after years living in disadvantaged environments. Notwithstanding, they suggest that with the implementation of intervention and attention training programs, socially disadvantaged students can learn to refocus attention. Based on the assumption that attention is malleable, incorporating cognitive training that suppresses distractors and enhances attention control, lower-SES students are more likely to improve selective attention and perform as well as higher-SES students (D'Angiulli, Herdman et al., 2008; D'Angiulli, Van Roon et al., 2012).

\subsection{Cognitive Training Programs}

It seems plausible to believe that by understanding how disadvantaged students' process information and by referring students to cognitive training intervention programs, teachers can help socially disadvantaged students achieve their true potential. A variety of cognitive training programs seem to contribute to the enhancement of attention, for example, mindfulness, yoga, exposure to nature, integrative body-mind training (IBMT; Tang \& Posner, 2009); action video games, particularly, Halo, Call of Duty, Counterstrike, Gears and War (Stevens \& Bavelier, 2012) and a special computer training program called Dual n Back Training (Jaeggi, Buschkuehl, Jonidas, \& Perrig, 2008).

Research on action video games addressing attentional bias provides encouraging evidence of improvements. Changes in gray and white matter and enhancements of attention control have been reported after playing action video games (Cardoso-Leite \& Bavelier, 2014). Furthermore, players display increased ability in different tasks that involve decision-making and top-down attentional control such as selective attention over space, time and objects. As the players learn to suppress distracting information effectively, they increase the speed of reaction 
time (Cardoso-Leite \& Bavelier, 2014).

Consistent with these findings the work of Neville et al. (2013) has shown positive outcomes among socially disadvantaged pre-kinder students. According to Neville et al. (2013), several weeks after the implementation of the Family-Based Training Program with children and parents, they observed significant improvements in attention and other cognitive functions. The inclusion of parents is part of the Family-Based Training Program. According to Neville and colleagues, parents attended two-hour classes during eight weeks plus some additional exercises that they had to perform with their children at home. At the end of the intervention program the children showed greater improvements in several aspects like neural measures of attention, language and IQ (Neville et al., 2013). Parents' participation seems to have been central to the improvements of children's attention and learning.

We consider that cognitive training programs in the form of mindfulness, yoga, exposure to nature, IBMT, computarized programs and particularly, action video games are potentially effective enhancing attention control either in children or adults.

\section{Protective Factors: Personal Traits and Caring Adults}

A significant longitudinal study performed in 1955 in Kauai, Hawaii, illustrates the capacity of low-income students to overcome adversities and succeed in school and life. In the study, Werner and Smith (1992) found that from 505 children who had experienced the cumulative effects of poverty, $10 \%$ were able to academically succeed, have productive lives, and remain mentally healthy even at mid-age (Werner, 1989). The study demonstrated that the combination of several protective factors (see Table 1) that included personal traits (e.g., high or normal IQ, social skills and ability to elicit positive responses from adults) and the influence of a caring adult like a family member, neighbor or teacher seems to have contributed to ameliorate or prevent the development of pathologies (Werner, 1989). The influence of a caring teacher appeared prominent. This kind of teacher was approachable, empathic and projected high expectations leaving long-lasting effects on students.

Table 1. Protective factors found in the Kauai study.

\section{Protective factors}

a. good temperament

b. four or less siblings

c. more than a two year difference in ages between the resilient child and the next sibling.

d. one or more caring adults like caring teachers in the child's life

e. the level of attention from the primary caregiver

f. internal locus of control

g. support from extended family members or friends

h. ability to elicit positive responses from adults

i. faith obtained from a religious group

j. academic skills

k. normal or high intelligence

1. a teacher as a role model

$\mathrm{m}$. participation in extracurricular activities, particularly those that promoted interaction and cooperation

n. involvement in hobbies

Closely similar to Werner and Smith's study, investigations with children of schizophrenic parents in the United Sates (Garmezy, 1971) and orphans from Romania and England (Rutter \& O'Connor, 2004), reinforce the idea of resilient functioning despite extremely difficult childhoods.

The combination of resilience, the assistance of a caring adult like a teacher, and the implementation of cognitive intervention training programs can be potentially helpful in moderating the effects of poverty and be conducive to learning and achievement. 


\section{Interventions and Brain Plasticity}

It is worth noting that brain plasticity plays a central role in improving executive functions. The cognitive process of obtaining corrective information, new input, feedback, establishing associations and reorganizing present and prior knowledge is possible due to the brain malleability that lasts throughout the lifespan (Stevens et al., 2009). Studies with rodents showed that after exposure to enriching environments, neuroanatomical changes in the form of increased brain size, brain weight and dendritic branching were reported (Bryck \& Fisher, 2012). Similar neurophysiological outcomes occur in human brains which may be indicative of the potential of intervention programs to correct executive functions deficits.

Nevertheless, Bryck and Fisher (2012) raise concerns about the lack of strong evidence indicating whether the positive outcomes obtained from laboratory-based training transfer to real world situations. In this regard, different studies seem to confirm that the benefits of cognitive training transfer to real life situations (see Klinghbergh et al., 2005; Rueda, Rothbart, McCandliss, Saccomano, \& Posner, 2005; Stevens \& Bavelier, 2012; Stevens, Fanning, Coch, Sanders, \& Neville, 2008). It seems that the amazing plasticity of the brain facilitates the correction of maladaptive information processing habits enabling the individual to perform effectively in real-world contexts.

\subsection{Parental Involvement}

It is worth noting that parental involvement has a positive impact on students' academic outcomes. According to Wang and Gordon (1994), parental involvement facilitates connection between school and home, increases attendance and improves academic achievement. Parental involvement also has positive effects during those interventions that address attentional problems, as the authors of the Family-Based Training Program model discussed earlier attest (Neville et al., 2013).

\section{Answer to Research Question}

We are of the opinion that the evidence presented in this article is strong enough as to answer our research question: Can low-income students with proper support improve academic performance? Our answer is yes because the evidence provided in our analysis shows that despite histories of poverty, abuse and neglect, in addition to high genetic risks, it is possible for at-risk individuals to bounce back from adversity, display competence in several domains and have productive lives. Interventions and cognitive training programs can be potentially effective in correcting executive functioning deficits related to attention.

We believe that now more than ever teachers count on important knowledge and resources that facilitates their mission. Full implementation of cognitive training programs in schools would increase the prospects of academic achievement among socially disadvantaged students.

\section{Conclusion}

A growing body of clinical experience and research supports the notion that chronicity of stress is more pervasive among lower-income individuals. Many of them have to deal with a confluence of multiple stressors that impact cognition, behavior and general health. Stressful experiences are cumulative leading to wear and tear that compromise selective attention and increase the risk of academic failure. It becomes central for teachers and others involved in education to understand that many of our students come from deprived, volatized and stressful environments that induce maladaptive information processing habits. Attentional deficits are a by-product of social inequality. Understanding this reality would entice teachers to refer disadvantaged students to cognitive training intervention programs that enhance students' cognition and facilitate success in school and life.

The present paper intends to yield a clear insight into the consequences of children's dramatic experiences that generate neurophysiological changes with implications on academic competence. This paper underscores the potential of intervention and cognitive training programs to reverse the negative effects of poverty. With this in mind this paper seeks to create awareness on the existence of effective paths that promote resilience, enhance attention, improve academic performance, and ultimately, reduce the academic achievement gap. Caring and effective teachers increase the students' likelihood of completing school and engaging in post-secondary education. Moreover, in the wake of a severe recession with declining opportunities, high unemployment and increased rates of school underachievement and desertion, many individuals find themselves at heightened risk of social exclusion. For this reason the school should represent an effective institution that produces intellectually competent individuals as a foundation to meaningful employment, ethical responsibility and full integration in society.

The hypothesis stated here clearly needs to be improved by more research. The studies on attention discussed in this paper were by no means comprehensive. We encourage investigation and expansion of scholarship in the 
field, promoting the development and implementation of effective educational policies designed to prevent and treat attentional deficits. Fortunately, now more than ever teachers count on effective tools designed to empower and engage learners, enhance academic skills and change life trajectories regardless of socioeconomic backgrounds.

\section{References}

Abramson, L. Y., Seligman M. E. P., \& Teasdale, J. (1978). Learned helplessness in humans: Critique and reformulation. Journal of Abnormal Psychology, 87(1), 49-74. http://dx.doi.org/10.1037/0021-843X.87.1.49

Alley, D. E., Seeman, T. E., Ki-Kim, J., Karlamangla, A., Hu, P., \& Crimmins, E. M. (2006). Socioeconomic status and C-reactive protein levels in the US population: NHANES IV. Brain Behavior and Immunity, 20(5), 498-504. http://dx.doi.org/10.1016/j.bbi.2005.10.003

Blaustein, M. E. (2013). Childhood trauma and a framefork for intervention. In E. Rossen, \& R. Hull (Eds.), Supporting and educating traumatized students (pp. 3-21). Oxford University Press.

Blaustein, M. E., \& Kinniburgh, K. (2010). Treating traumatic stress in children and adolescents: How to foster resilience through attachment, self-regulation, and competency. New York, NY: Guilford Press.

Bolland, J. M. (2003). Hopelessness and risk behaviour among adolescents living in high-poverty inner-city $\begin{array}{llll}\text { neighbourhoods. Journal } & \text { of }\end{array}$ http://dx.doi.org/10.1016/S0140-1971(02)00136-7

Brooks-Gunn, J., \& Duncan, G. J. (1997). The effects of poverty on children. The Future Children, 7(2), 55-71.

Bryck, R. L., \& Fisher, P. A. (2012). Training the brain: Practical applications of neural plasticity from the intersection of cognitive neuroscience, developmental psychology, and prevention science. American Psychologist, 67, 87-100. http://dx.doi.org/10.1037/a0024657

Cardoso-Leite, P., \& Bavelier, D. (2014). Video game play, attention, and learning: How to shape the development of attention and influence learning? Current Opinion in Neurology, 27, 185-191. http://dx.doi.org/10.1097/WCO.0000000000000077

Caspi, A., Wright, B. R. E., Moffitt, T. E., \& Silva, P. A. (1998). Early failure in the labor market: Childhood and adolescent predictors of unemployment in the transition to adulthood. American Sociological Review, 63(3), 424-451. http://dx.doi.org/10.2307/2657557

Chaffin, M., Kelleher, K., \& Hollenberg, J. (1996). Onset of physical abuse and neglect: Psychiatrict, substance abuse, and social risk factors from prospective community data. Child Abuse and Neglect, 20(3), 191-203.

Cicchetti, D., \& Rogosch, F. A. (2007). Personality, adrenal steroid hormones, and resilience in maltreated children: A multilevel perspective. Development and Psychopathology, 19(03), 787-809. http://dx.doi.org/10.1017/S0954579407000399

Cicchetti, D., \& Toth, S. L. (2005). Child maltreatment. Annual Revision of Clinical Psychology, 1, 409-438. http://dx.doi.org/10.1146/annurev.clinpsy.1.102803.144029

Cicchetti, D., Rogosch, F. A., Gunnar, M. R., \& Toth, S. L. (2010). The Differential Impacts of Early Physical and Sexual Abuse and Internalizing Problems on Daytime Cortisol Rhythm in School-Aged Children. Child Development, 81(1), 252-269. http://dx.doi.org/10.1111/j.1467-8624.2009.01393.x

D’Angiulli, A., Herdman, A., Stapells, D., \& Hertzman, C. (2008). Children's event-related potentials of auditory selective attention vary with their socioeconomic status. Neuropsychology, 22(3), 293-300. http://dx.doi.org/10.1037/0894-4105.22.3.293

D’Angiulli, A., Lipina, S. J., \& Olesinska, A. (2012). Explicit and implicit issues in the developmental cognitive neuroscience of social inequality. Frontiers in Human Neuroscience, 6(254), 1-17. http://dx.doi.org/10.3389/fnhum.2012.00254

D’Angiulli, A., Van Roon, P. M., Weinberg, J., Oberlander, T. F., Grunau, R. E., Hertzman, C., \& Maggi, S. (2012). Frontal EEG/ERP correlates of attentional processes, cortisol and motivational states in adolescents from lower and higher socioeconomic status. Frontiers in Human Neuroscience. http://dx.doi.org/10.3389/fnhum.2012.00306

D'Angiulli, A., Weinberg, J., Grunau, R., Hertzman, C., \& Grebenkov, P. (2008). Towards a cognitive science of social inequality: children's attention-related ERPs and salivary cortisol vary with their socioeconomic status. In Proceedings of the 30th Cognitive Science Society Annual Meeting (pp. 211-216). Retrieved from 
http://csjarchive.cogsci.rpi.edu/proceedings/2008/pdfs/p211.pdf

Danese, A., \& McEwen, B. S. (2012). Adverse childhood experiences, allostasis, allostatic load, and age-related disease. Physiology \& Behavior, 106(1), 29-39. http://dx.doi.org/10.1016/j.physbeh.2011.08.019

Delahanty, D. L., Nugent, N. R., Christopher, N. C., \& Walsh, M. (2005). Initial urinary epinephrine and cortisol levels predict acute PTSD symptoms in child trauma victims. Psychoneuroendocrinology, 30(2), 121-128. http://dx.doi.org/10.1016/j.psyneuen.2004.06.004

Doll, B., \& Lyon, M. (1998). Risk and Resilience: Implications for the delivery of educational and mental health services in the schools. School Psychology Review, 27(3), 348-363.

Drake, B., \& Pandey, S. (1996). Understanding the relationship between neighborhood poverty and specific types of child maltreatment. Child Abuse \& Neglect, 20(11), 1003-1018. http://dx.doi.org/10.1016/0145-2134(96)00091-9

Dube, S. R., Felitti, V. J., Dong, M., Chapman, D. P., Giles, W. H., \& Anda, R. F. (2003). Childhood abuse, neglect, and household dysfunction and the risk of illicit drug use: The adverse childhood experiences study. Pediatrics, 111(3), 564-572. http://dx.doi.org/10.1542/peds.111.3.564

Duncan, G. J. (2012). Give us this day our daily breadth. Child Development, 83(1), 6-16. http://dx.doi.org/10.1111/j.1467-8624.2011.01679.x

Duncan, G. J., \& Rodgers, W. (1998). Longitudinal aspects of childhood poverty. Journal of Marriage and the Family, 50, 1007-1021.

Evans, G. W., \& Kim, P. (2013). Childhood poverty, chronic stress, self-regulation, and coping. Child Development Perspectives, 7, 43-48. http://dx.doi.org/10.1111/cdep.12013

Evans, G. W., Chen, E., Miller, G. E., \& Seeman, T. E. (2012). How poverty gets under the skin: A life course perspective. In V. Maholmes, \& R. B. King (Eds.), The Oxford handbook of poverty and child development (pp. 13-36). Oxford University Press.

Farah, M. J., \& Hackman, D. A. (2012). SES, childhood experience, and the neural bases of cognition. In V. Maholmes, \& R. B. King (Eds.), The Oxford handbook of poverty and child development (pp. 307-318). Oxford University Press.

Forman, S. G., Olin, S. S., Hoagwood, K. E., Crowe, M., \& Saka, N. (2009). Evidence-based interventions in schools: developers' views of implementation barriers and facilitators. School Mental Health, 1(1), 26-36. http://dx.doi.org/10.1007/s12310-008-9002-5

Garmezy, N. (1971). Vulnerability research and the issue of primary prevention. American Journal of Orthopsychiatry, 41(1), 101-116. http://dx.doi.org/10.1111/j.1939-0025.1971.tb01111.x

Hackman, D. A., \& Farah, M. J. (2009). Socioeconomic status and the developing brain. Trends in Cognitive Sciences, 13(2), 65-73. http://dx.doi.org/10.1016/j.tics.2008.11.003

Hackman, D. A., Farah, M. J., \& Meaney, M. J. (2010). Socioeconomic status and the brain: Mechanistic insights from human and animal research. Nature Reviews Neuroscience, 11(9), 651-659. http://dx.doi.org/10.1038/nrn289

Hoff, E. (2003). The specificity of environmental influence: Socioeconomic status affects early vocabulary development via maternal speech. Child Development, 74(5), 1368-1378. http://dx.doi.org/10.1111/1467-8624.00612

Jaeggi, S. M., Buschkuehl, M., Jonides, J., \& Perrig, W. J. (2008). Improving fluid intelligence with training on working memory. Proceedings of the National Academy of Sciences, 105(19), 6829-6833. http://dx.doi.org/10.1073/pnas.0801268105

Jaffee, S. R., \& Maikovich-Fong, A. K. (2011). Effects of chronic maltreatment and maltreatment timing on children's behavior and cognitive abilities. Journal of Child Psychology and Psychiatry, 52(2), 184-194. http://dx.doi.org/10.1111/j.1469-7610.2010.02304.x

Klingberg, T., Fernell, E., Olesen, P. J., Johnson, M., Gustafsson, P., Dahlstrom, K., . . W Westerberg, H. (2005). Computerized training of working memory in children with ADHD-A. Randomized, Controlled Trial Journal of the American Academy of Child \& Adolescent Psychiatry, 44(2), 177-186. http://dx.doi.org/10.3389/fpsyg.2015.01081

Lutz, A., Slagter, H. A., Rawlings, N. B., Francis, A. D., Greischar, L. L., \& Davidson, R. J. (2009). Mental 
training enhances attentional stability: neural and behavioral evidence. The Journal of Neuroscience, 29(42), 13418-13427. http://dx.doi.org/10.1523/JNEUROSCI.1614-09.2009

Mani, A., Mullainathan, S., Shafir, E., \& Zhao, J. (2013). Poverty impedes cognitive functions. Science, 341(6149), 976-980. http://dx.doi.org/10.1126/science.1238041

Masten, A. S., Desjardins, C. D., McCormick, C. M., Kuo, S. I. C., \& Long, J. D. (2010). The significance of childhood competence and problems for adult success in work: A developmental cascade analysis. Development and Psychopathology, 22(3), 679. http://dx.doi.org/10.1017/S0954579410000362

McEwen, B. S., \& Gianaros, P. J. (2010). Central role of the brain in stress and adaptation: Links to socioeconomic status, health, and disease. Annals of the New York Academy of Sciences, 1186(1), 190-222.

Neville, H. J., Stevens, C., Pakulak, E., Bell, T. A., Fanning, J., Klein, S., \& Isbell, E. (2013). Family-based training program improves brain function, cognition, and behavior in lower socioeconomic status preschoolers. Psychological and Cognitive Sciences. http://dx.doi.org/10.1073/pnas.1304437110

Perez, C. M., \& Widom, C. S. (1994). Childhood victimization and long-term intellectual and academic outcomes. Child Abuse \& Neglect, 18(8), 617-633. http://dx.doi.org/10.1016/0145-2134(94)90012-4

Radford, L., Corral, S., Bradley, C., \& Fisher, H. L. (2013). The prevalence and impact of child maltreatment and other types of victimization in the UK: Findings from a population survey of caregivers, children and young people and young adults. Child Abuse \& Neglect, 37(10), 801-813. http://dx.doi.org/10.1016/j.chiabu.2013.02.004

Rogosch, F. A., Dackis, M. N., \& Cicchetti, D. (2011). Child maltreatment and allostatic load: Consequences for physical and mental health in children from low-income families. Development and Psychopathology, 23(4), 1107-1124. http://dx.doi.org/10.1017/S0954579411000587.

Rueda, M. R., Rothbart, M. K., McCandliss, B. D., Saccomanno, L., \& Posner, M. I. (2005). Training, maturation, and genetic influences on the development of executive attention. Proceedings of the National Academy of Sciences of the United States of America, 102(41), 14931-14936. http://dx.doi.org/10.1073/pnas.0506897102

Rutter, M., \& O’Connor, T. G. (2004). Are there biological programming effects for psychological development? Findings from a study of Romanian adoptees. Developmental Psychology, 40(1), 81-94. http://dx.doi.org/10.1037/0012-1649.40.1.81

Sampson, R. J., Sharkey, P., \& Raudenbush, S. W. (2007). Durable effects of concentrated disadvantage on verbal ability among African-American children. Proceedings of the National Academy of Sciences, 105(3), 845-852. http://dx.doi.org/10.1073/pnas.0710189104

Schibli, K., \& D'Angiulli, A. (2011). The neuroscience of poverty: Implications for teaching. Education Canada, 51(2), 17-20. Retrieved from http://www.cea-ace.ca/education-canada/article/neuroscience-povertyimplications-teaching

Shackman, J. E., Shackman, A. J., \& Pollak, S. D. (2007). Physical abuse amplifies attention to threat and increases anxiety in children. Emotion, 7(4), 838-852.

Shah, A. K., Mullainathan, S., \& Shafir, E. (2012). Some consequences of having too little. Science, 338(6107), 682-685. http://dx.doi.org/10.1126/science.1222426

Speth, T., Saifer, S., \& Forehand, G. (2008). Parent involvement activities in school improvement plans in the Northwest Region (Issues \& Answers Report, REL 2008-No. 064). Washington, DC: U.S. Department of Education, Institute of Education Sciences. Retrieved from http://ies.ed.gov/ncee/edlabs

Stabb, S., \& Reimers, F. (2013). Competent poverty training. Journal of Clinical Psychology, 69(2). 172-181. http://dx.doi.org/10.1002/jclp.21956

Staff, R. T., Murray, A. D., Ahearn, T. S., Mustafa, N., Fox, H. C., \& Whalley, L. J. (2012). Childhood socioeconomic status and adult brain size: Childhood socioeconomic status influences adult hippocampal size. Annals of Neurology, 71(5), 653-660. http://dx.doi.org/10.1002/ana.22631

Steinberg, L., Catalano, R., \& Dooley, D. (1981). Economic antecedents of child abuse and neglect. Child Development, 52(3), 975-985. http://dx.doi.org/10.2307/1129102

Stevens C., Fanning, J., Coch, D., Sanders, L., \& Neville, H. (2008). Neural mechanisms of selective auditory attention are enhanced by computerized training: Electrophysiological evidence from language-impaired 
and typically developing children. Brain Research, 1205, 55-69.

Stevens, C., \& Bavelier, D. (2012). The role of selective attention on academic foundations: A cognitive neuroscience perspective. Developmental Cognitive Neuroscience, 2, S30-S48. http://dx.doi.org/10.1016/j.den.2011.11.001

Stevens, C., Lauinger, B., \& Neville, H. (2009). Differences in the neural mechanisms of selective attention in children from different socioeconomic backgrounds: An event related brain potential study. Developmental Science, 12(4), 634-646. http://dx.doi.org/10.1111/j.1467-7687.2009.00807.x

Tang, Y. Y., \& Posner, M. (2009). Attention training and attention state training. Trends in Cognitive Science, 13(5), 222-227. http://dx.doi.org/10.1016/j.tics.2009.01.009

Teicher, M. H., Anderson, C. M., \& Polcari, A. (2012). Childhood maltreatment is associated with reduced volume in the hippocampal subfields CA3, dentate gyrus, and subiculum. Proceedings of the National Academy of Sciences, 109(9), E563-E572. http://dx.doi.org/10.1073/pnas.1115396109

Tottenham, N., \& Sheridan, M. A. (2009). A review of adversity, the amygdala and the hippocampus: A consideration of developmental timing. Frontiers in Human Neuroscience, 3. http://dx.doi.org/10.3389/neuro.09.068.2009

Turner, M. A., Popkin, S. J., \& Rawlings, L. (2008). Public housing and the legacy of segregation. Urban Institute Press.

Ursin, H., \& Eriksen, H. R. (2004). The cognitive activation theory of stress. Psychoneuroendocrinology, 29(5), 567-592. http://dx.doi.org/10.1016/S0306-4530(03)00091-X

Wachs, T. D., \& Evans, G. W. (2009). Chaos in context. In G. W. Evans, \& T. D. Wachs (Eds.), Chaos and its influence on children's development: An ecological perspective (pp. 3-14). Washington DC: American Psychological Association. http://dx.doi.org/10.1037/12057-001

Wang, M. C., \& Gordon, E. W. (1994). Educational resilience in inner-city America. Hillsdale, NJ: Erlbaum.

Wegman, L., \& O’Banion, M. (2013). Students affected by physical and emotional abuse. In E. Rossen, \& R. Hull (Eds.), Supporting and educating traumatized students (pp. 219-228). Oxford University Press.

Werner, E. E. (1989). High-risk children in young adulthood: A longitudinal study from birth to 32 years. The American Journal of Orthopsychiatry, 59, 72. http://dx.doi.org/10.1111/j.1939-0025.1989.tb01636.x

Werner, E. E., \& Smith, R. S. (1992). Overcoming the odds: High risk children from birth to adulthood. Cornell University Press: Ithaca and London.

Zielinski, D. S. (2009). Child maltreatment and adult socioeconomic well-being. Child Abuse \& Neglect, 33(10), 666-678. http://dx.doi.org/10.1016/j.chiabu.2009.09.001

\section{Copyrights}

Copyright for this article is retained by the author(s), with first publication rights granted to the journal.

This is an open-access article distributed under the terms and conditions of the Creative Commons Attribution license (http://creativecommons.org/licenses/by/3.0/). 